\title{
HYDROLOGIC AND GEOCHEMICAL DYNAMICS OF VADOSE ZONE RECHARGE IN A MANTLED KARST AQUIFER: RESULTS OF MONITORING DRIP WATERS IN MYSTERY CAVE, MINNESOTA
}

\author{
Daniel H. Doctor
}

U.S. Geological Survey, 12201 Sunrise Valley Drive, MS 926A, Reston, Virginia, 20192,

dhdoctor@usgs.gov

E. Calvin Alexander, Jr.

University of Minnesota, Department of Earth Sciences, 310 Pillsbury Drive SE Minneapolis, MN 55455-0231, alexa00l@umn.edu

Roy A. Jameson

1808 Gardenspring Drive, Blacksburg, Virginia,24060,rjcb19@comcast.net

\section{Scott C. Alexander}

University of Minnesota, Department of Earth Sciences, 310 Pillsbury Drive SE, Minneapolis, MN 55455-0231, alexa017@umn.edu

\section{Abstract}

Caves provide direct access to flows through the vadose zone that recharge karst aquifers. Although many recent studies have documented the highly dynamic processes associated with vadose zone flows in karst settings, few have been conducted in mantled karst settings, such as that of southeastern Minnesota. Here we present some results of a long-term program of cave drip monitoring conducted within Mystery Cave, Minnesota. In this study, two perennial ceiling drip sites were monitored between 1997 and 2001. The sites were located about $90 \mathrm{~m}$ (300 $\mathrm{ft}$ ) apart along the same cave passage approximately $18 \mathrm{~m}$ ( $60 \mathrm{ft}$ ) below the surface; 7 to $9 \mathrm{~m}$ ( 20 to $30 \mathrm{ft}$ ) of loess and $12 \mathrm{~m}$ (40 ft) of flat-lying carbonate bedrock strata overlie the cave. Records of drip rate, electrical conductivity, and water temperature were obtained at 15 minute intervals, and supplemented with periodic sampling for major ion chemistry and water stable isotopes. Patterns in flow and geochemistry emerged at each of the two drip sites that were repeated year after year. Although one site responded relatively quickly (within 2-7 hours) to surface recharge events while the other responded more slowly (within 2-5 days), thresholds of antecedent moisture needed to be overcome in order to produce a discharge response at both sites. The greatest amount of flow was observed at both sites during the spring snowmelt period. Rainfall events less than $10 \mathrm{~mm}$ (0.4 in) during the summer months generally did not produce a drip discharge response, yet rapid drip responses were observed following intense storm events after periods of prolonged rainfall. The chemical data from both sites indicate that reservoirs of vadose zone water with distinct chemical signatures mixed during recharge events, and drip chemistry returned to a baseline composition during low flow periods. A reservoir with elevated chloride and sulfate concentrations impacts the slow-response drip site with each recharge event, but does not similarly affect the fast-response drip site. Nitrate concentrations in drip waters were generally less than $4.0 \mathrm{mg} / \mathrm{L}$ as $\mathrm{NO}_{3}^{-}$(or less than 1 $\mathrm{mg} / \mathrm{L}$ as N). Nitrate was either stable or slightly increased with drip rate at the fast-response drip site; in contrast, nitrate concentrations decreased with drip rate at the slowresponse drip site.

\section{Introduction}

The vadose zone is the principal pathway for autogenic recharge of karst aquifers. Many recent studies have been conducted on characterizing vadose zone flow in karst (see Fairchild et al., 2006 and Fairchild and Baker, 2012 for reviews); however, the processes controlling flow through the vadose zone in karst settings are still not very well understood. Due to the potential for high flow velocities and rapid transmission of infiltrating water through the vadose zone in karst, these aquifers may be highly susceptible to pollutants applied to the land surface. In a karst system where a mantle of sediment overlying bedrock is thick, the aquifer might be considered to be more 'protected' from the influence of surface pollution (e.g., Döerfliger et al, 1999); however, relatively few studies of cave drip water chemistry have been conducted in mantled karst settings. 
Here we present some results of a long-term program of cave drip monitoring conducted between 1997-2001 within Forestville/MysteryCave State Park, Fillmore County, Minnesota. In southeastern Minnesota, the karst is mantled by a layer of post-glacial loess measuring up to $9 \mathrm{~m}$ (30 ft) thick in some areas. Although preferential flow through macropores may allow water to infiltrate rapidly, the fine sediment matrix also retards flow and allows for water retention. The degree to which water is transmitted or retained is thus highly dependent upon antecedent hydrologic conditions.

Fertilizer and pesticide pollutants such as nitrate and atrazine are commonly detected in shallow carbonate aquifers of southeastern Minnesota due to agricultural practices on the surface. These chemicals migrate down through the vadose zone, and may accumulate in the epikarst and/or saturated zone (Kamas et al., 2015; Huebsch et al., 2014). For example, Alexander et al. (1999) reported that an anthropogenic $\mathrm{Ca}+\mathrm{Mg} / \mathrm{Cl}+\mathrm{NO}_{3}$ chemical component of up to $6 \mathrm{meq} / \mathrm{kg}$ is detectable in some
Minnesota groundwaters. Early results from the present study indicated that these chemicals are also retained within the vadose zone, in similar concentrations (Doctor and Alexander, 1998). This strong anthropogenic chemical component acts as a marker of young groundwater ages, since this chemical signature is not seen in aquifers that have ages older than the onset of intensive agricultural practices in Minnesota (Alexander et al., 1999).

\section{Study Area}

This study took place within the eastern portion of Mystery Cave (Figure 1). Mystery Cave is managed by the Minnesota Department of Natural Resources, whose cooperation greatly facilitated this study. The cave is developed in flat-lying limestone and dolomite rocks of Paleozoic age. Two bedrock units contain the majority of the cave passages: the Dubuque Formation, and the dolomitic Stewartville Formation of the Galena Group. The Dubuque is composed of intercalated limestone and calcareous shales, and overlies the more massive Stewartville dolomite.

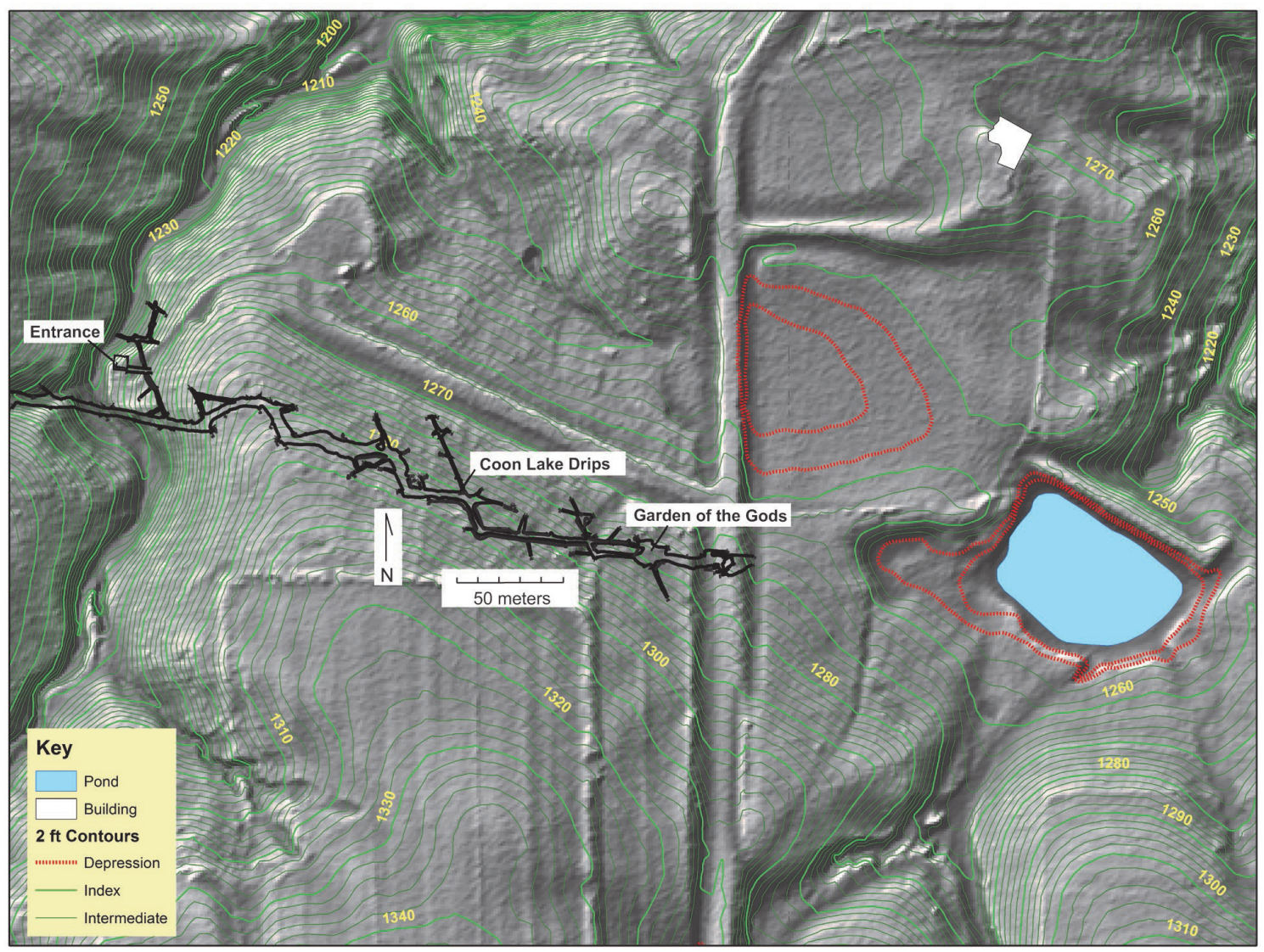

Figure 1. The study area, showing a map of the cave passage and the drip sites overlain on a LiDAR-derived elevation base with 2 foot contours (LIDAR data provided by the Minnesota Department of Natural Resources). The elevation of the pond is $1250 \mathrm{ft}$. 
Two perennially dripping sites within the cave were monitored. Both of these sites are located along the tourist route in the portion of the cave called Mystery II, where the passages are formed primarily within the Stewartville dolomite. In many places the passage ceiling marks the contact between the Dubuque and the Stewartville units, labeled BP1 by Palmer and Palmer (1993), as shown in Figure 2.

The first drip site is named Coon Lake Drips (CLD). Here, water enters the cave as it flows out of a vertical joint fracture in the ceiling, and then runs down the wall of the passage, depositing a rind of calcite flowstone. The water drips onto the floor, and runs across the footpath in the main passage into a small ephemeral pool on the other side called Coon Lake. Coon Lake Drips and Coon Lake have essentially identical water chemistries during periods of relatively high discharge ( $>2 \mathrm{~L} / \mathrm{hr}$ ) at the drips (Jameson and Alexander, 1994).

The second site is located further down the passage within a room called Garden of the Gods (GG). This room is one of the more highly decorated parts of the cave, exhibiting numerous stalactites and stalagmites and an abundance of flowstone. The dampness and associated speleothem growth at Garden of the Gods indicates that this area of the cave is a significant focal point for discharge of vadose zone waters held in storage above the cave. The soda straw stalactites number in the hundreds, however only three drip sites have been observed to show measurably variable discharge on hourly time scales; these drips have been designated GG1, GG2 and GG3. Only GG1 discharges water perennially and thus was chosen as the site to be instrumented for this study. Since only data from the GG1 drip site is presented in this paper, the site will hereafter be referred to as GG. Water at GG drips off of five distinct stalactites; however, all five extend off of a singular flowstone deposit originating as seepage from a bedding plane parting near to the ceiling.

The land surface above the two drip sites slopes gently to the northeast, and is partially natural grassland, and partially agricultural land. A driveway leading to the entrance of the cave runs along the base of the hillslope, and the passage along which the drip sites are located lies beneath the hillslope, roughly parallel to the driveway. From the chemical data obtained, it is apparent that the drip waters in the cave are affected by the agricultural activity overlying or in the immediate vicinity of the cave.

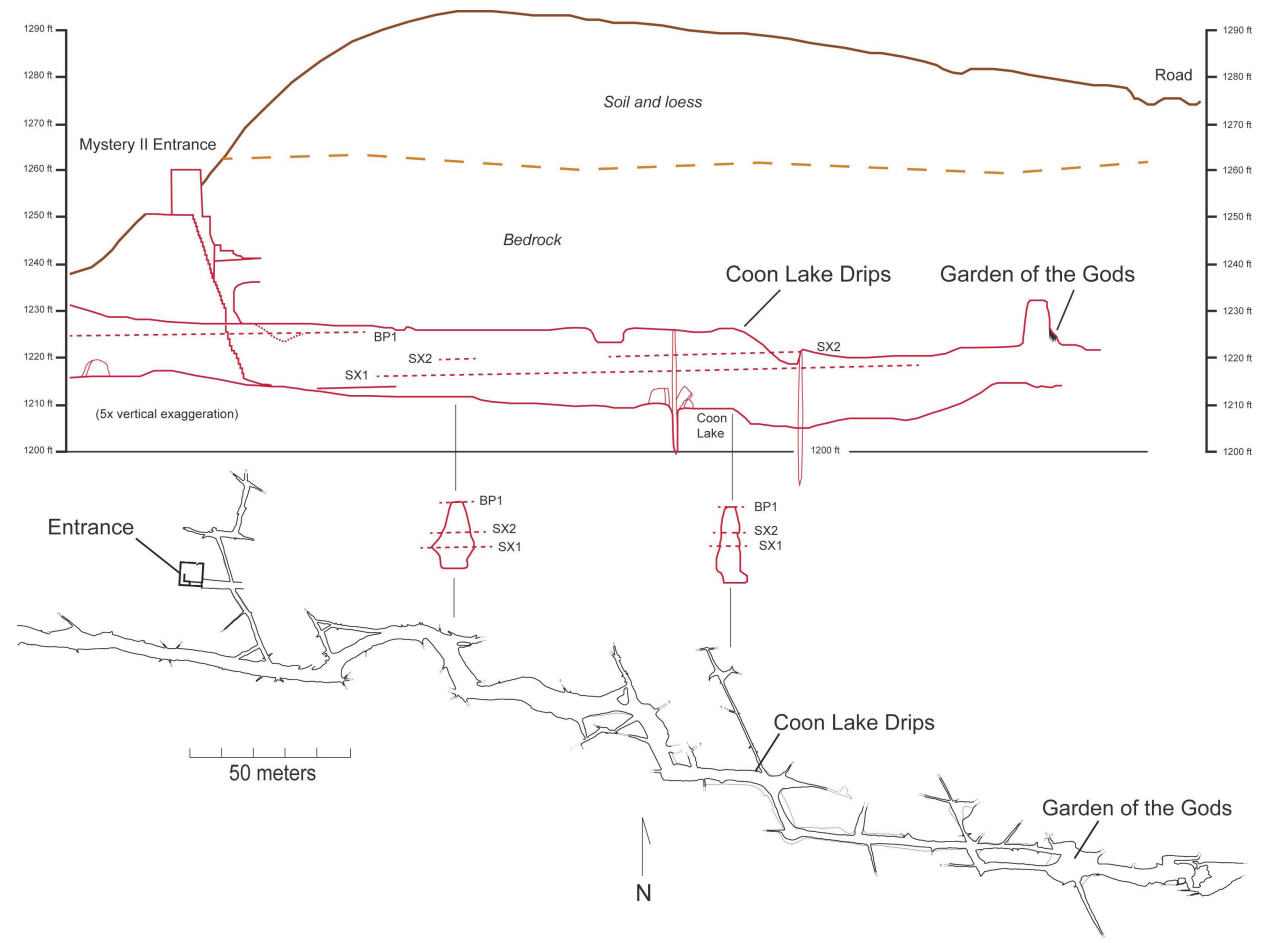

Figure 2. Map and extended profile of the section of Mystery Cave studied. Cave map provided courtesy of Warren Netherton, Forestville/Mystery Cave State Park; extended cave profile modified from Palmer and Palmer, 1993. Surface profile obtained from LIDAR elevation data provided by the Minnesota Dept. of Natural Resources. BP1, SX1, SX2 indicate bedding plane horizons. 
Shallow seismic surveys conducted directly over the two

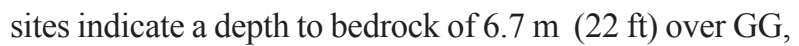
and $8.5 \mathrm{~m}$ (28 ft) over CLD. A fairly uniform deposit of loess, laid down by wind during the last glacial retreat, mantles the bedrock. Detailed surveying from the drip sites through the cave and onto the surface indicate that the bedrock strata above the two drip sites are approximately 9 to $12 \mathrm{~m}$ (30-40 ft) thick. Water which falls as precipitation onto the surface must infiltrate through the soil, loess, and rock before entering the cave at the drips. Vertical flow paths are generally assumed to control the movement of water from the surface to the drips given the prominent vertical joints in the rock; however, significant horizontal flow paths along bedding plane partings cannot be ruled out, and may play a critical role in determining the hydrologic dynamics of the drips.

\section{Research Approach and Methods}

In order to characterize temporal hydrologic and chemical changes at the drips, a system was set up whereby the drip waters were funneled into a reservoir that spilled out into a rain gauge, and the flow was continuously monitored for drip rate, water temperature, and specific electrical conductance. The instrumentation setup is illustrated in Figure 4.

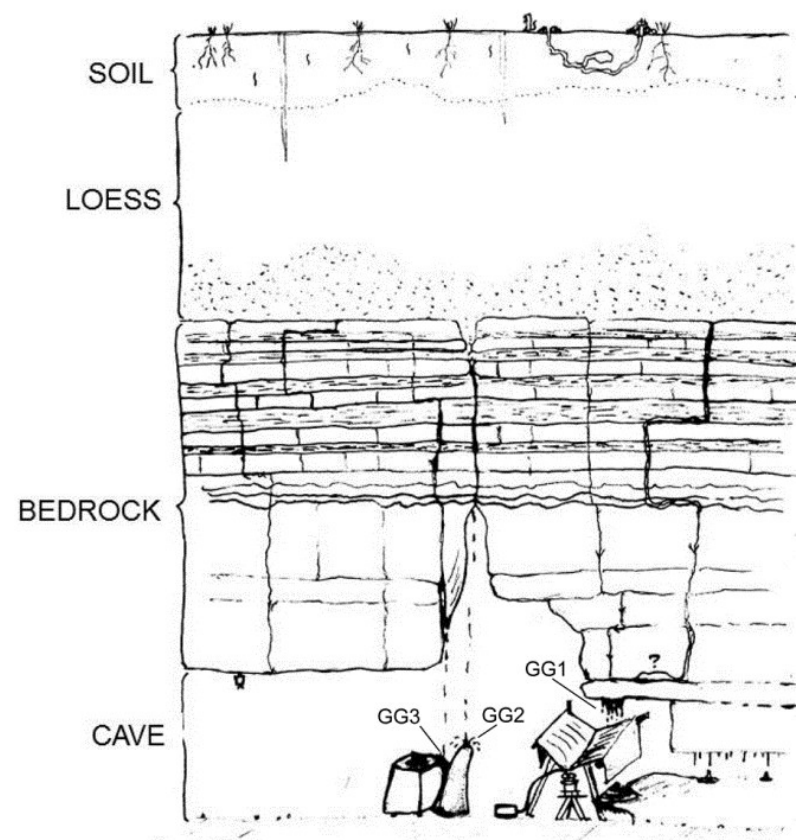

Figure 3. Schematic sketch of rock and sediment above the Garden of the Gods drip site (GG). Only GG1 was instrumented, and is referred to as $G G$ in the text.
The drip water fell into a funnel which rests in a reservoir of approximately $100 \mathrm{ml}$. The reservoir bottle has holes drilled around the top, below the base of the funnel, to allow water to freely flow out of the reservoir as fresh drip water is added. The water coming out of the top of the reservoir bottle then flows into a tipping-bucket rain gauge, which measures the discharge. Each tip of the rain gauge bucket equals $4.73 \mathrm{~mL}$. Inside the reservoir, within the funnel, rests a conductivity/water temperature probe. The probe and the rain gauge are connected to a data logger. The logger is programmed to take a conductivity/ temperature measurement every minute, then to record the average of those measurements every 15 minutes. The logger also sums the number of tips from the rain gauge, and records that sum every 15 minutes.

Water samples were collected approximately twice per month through the first half of 1997, and more frequently during a snowmelt event in 2001 . The $\mathrm{pH}$ and temperature of the samples were measured in the field, and splits collected for analysis of major cations and anions (15 $\mathrm{ml}$ for each) and stable isotopes of water (about $5 \mathrm{ml}$ ). The alkalinity of each sample was determined by manual titration within $24 \mathrm{hrs}$ of sample collection. Cations were measured using an inductively-coupled plasma mass

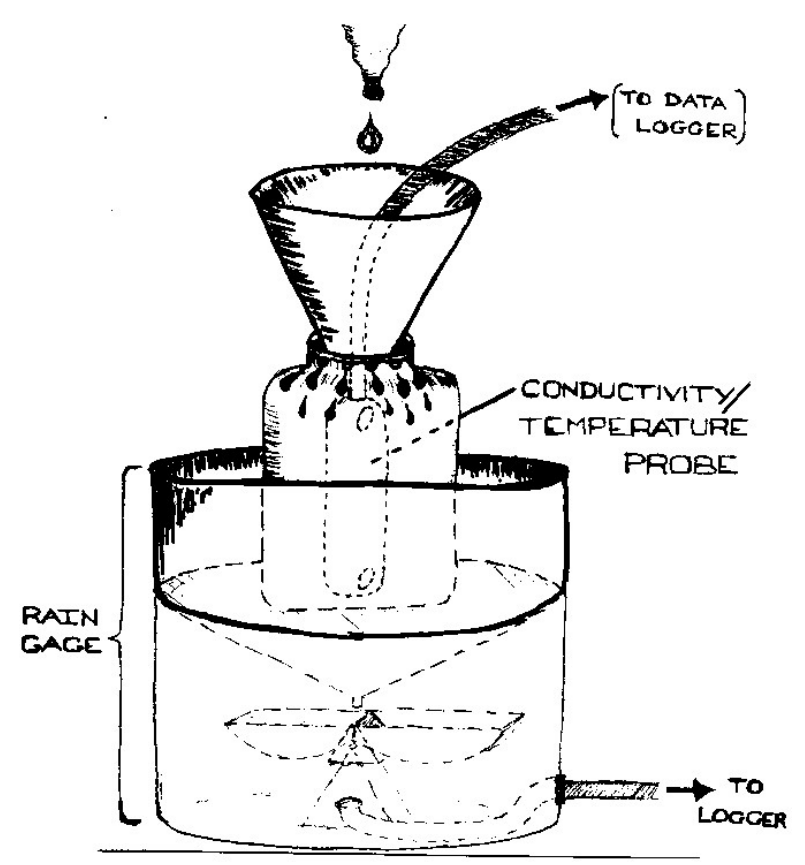

Figure 4. Drip monitoring setup within Mystery Cave. 
spectrometer (ICP-MS), and anions were measured by liquid chromatography at the University of Minnesota. Samples obtained for $\mathrm{O}$ and $\mathrm{H}$ stable isotope analysis of drip water were analyzed at the USGS in Denver, Colorado, and at the University of Missouri, St Louis. The stable isotope samples were stored in glass vials with polyseal caps to prevent evaporation.

A weather station was set up on the surface, approximately $100 \mathrm{~m}$ from the visitor center and near entrance of the main cave. The weather station recorded total rainfall, relative humidity, and air temperature every 15 minutes, and was synchronous with the dataloggers at the drip sites. This enabled records of drip discharge to be directly compared with surface precipitation. Snow depth data were obtained from a weather station at Preston, Minnesota, approximately $18 \mathrm{~km}$ from the research site.

\section{Results}

The continuous monitoring of the drip waters has illustrated distinct differences between the two sites. The faster-flowing drip site, CLD, shows rapid response to rain and snowmelt recharge. Drip rate at CLD can increase in a matter of minutes after rainfall, depending upon antecedent moisture conditions. Drip rates over 14 $\mathrm{L} / \mathrm{hr}$ have been measured. In contrast, the drip rate at GG rarely rises above $2.0 \mathrm{~L} / \mathrm{hr}$ (Figure 5).

The electrical conductivity and water chemistry data at GG has revealed a consistent increase in dissolved ion concentrations with an increase in drip rate, irrespective of the amount of the increase in drip rate. For example, a snowmelt event in early March of 1997 caused the drip rate to increase from less than 0.5 to $2.0 \mathrm{~L} / \mathrm{hr}$ at $\mathrm{GG}$, and the electrical conductance increased from 0.27 to 0.40 $\mathrm{mS} / \mathrm{cm}$. In October the same year, rainfall caused the drip rate to increase to roughly $1.0 \mathrm{~L} / \mathrm{hr}$, yet the conductivity increased again to nearly $0.40 \mathrm{mS} / \mathrm{cm}$. More stable water chemistry irrespective of discharge is seen at CLD. The discharge at CLD is consistently greater than that at GG year round (Figure 5). In addition, CLD responds much faster to large precipitation events on the surface (lag time on the order of 15 minutes) than at GG (lag time on the order of two days).

Chemical constituents such as nitrate $\left(\mathrm{NO}_{3}^{-}\right)$, chloride $\left(\mathrm{Cl}^{-}\right)$, and sulfate $\left(\mathrm{SO}_{4}{ }^{2-}\right)$ have been detected in the drip waters. Measured concentrations range up to $30 \mathrm{mg} / \mathrm{L}$ $\mathrm{SO}_{4}^{2-}, 23 \mathrm{mg} / \mathrm{L} \mathrm{Cl}^{-}$, and up to $4.0 \mathrm{mg} / \mathrm{L} \mathrm{NO}_{3}^{-}$at the $\mathrm{GG}$ site. Between 1997 and 2001, concentrations of these constituents were observed to increase at the GG drip site (Figure 6 and Figure 7). The concentrations vary according to the flow conditions, with apparent storage and buildup of these chemicals within a reservoir above the cave. Chloride and sulfate concentrations tend to co-vary, and increase with increases in discharge; in contrast, nitrate concentrations appear to have decreased with increases in discharge at GG in 2001. Although some data on drip rate and conductance was lost in 2001 due to instrument failure, it is evident from the patterns in earlier years (Jameson and Alexander, 1994) that these chemical changes are related to recharge events, coincident with the recharge events recorded at CLD.

\section{Conductivity and Discharge Relations}

CLD shows very little change in conductivity with increasing drip rate during snowmelt events or even during large summer storms, except at peak flows. Only during the highest drip rates $(>\sim 10 \mathrm{~L} / \mathrm{hr})$ does the conductivity decrease in response to drip rate at this site, exhibiting only a modest change of $0.015-0.030 \mathrm{mS}$, although that change can occur rapidly. For example, during the snowmelt of 1997 , the conductivity decreased from 0.260 to $0.245 \mathrm{mS}$ over the course of 6 hours, from March 27-28. Similarly, during a large summer rain storm event on June 27-28, 1998, the conductivity decreased only from 0.288 to $0.267 \mathrm{mS}$ over the course of 4 hours (Figure 8).

At CLD, the seasonal difference in drip water conductivity (between winter and summer) is greater than the change in conductivity across any single event, and the greatest change occurs during the transition between the end of spring snowmelt and the onset of the growing season. In both 1997 and 1998 the greatest conductivity increase took place from June through August, and after early September the conductivity began to level off and then decrease once again. This behavior is likely the result of the increased partial pressure of $\mathrm{CO}_{2}$ due to biological respiration in the soil zone during the growing season, which allows for greater carbonate mineral solution and/or a reduction in prior calcite precipitation (PCP) in the bedrock above the cave (Wong et al., 2011). Once the growing season ends, plants and microorganisms gradually reduce the production of $\mathrm{CO} 2$ due to respiration, and the total dissolved solids in the drip water gradually decreases. In contrast, the changes in conductivity at GG are much greater than at CLD, and 
there is little seasonal influence on the conductivity at GG. The changes in conductivity at this site are a direct function of the drip discharge. Every discernible flow event, irrespective of its magnitude, produces a change in conductivity at the drips that is nearly equivalent in its maximum value (Figure 5).

\section{Hysteresis}

Hysteresis plots of discharge versus conductivity show distinct patterns between the two drip sites, and among different seasons. A modest increase in drip rate at GG causes a large increase in conductivity, and the conductivity peaks prior to drip rate. At CLD, a rapid

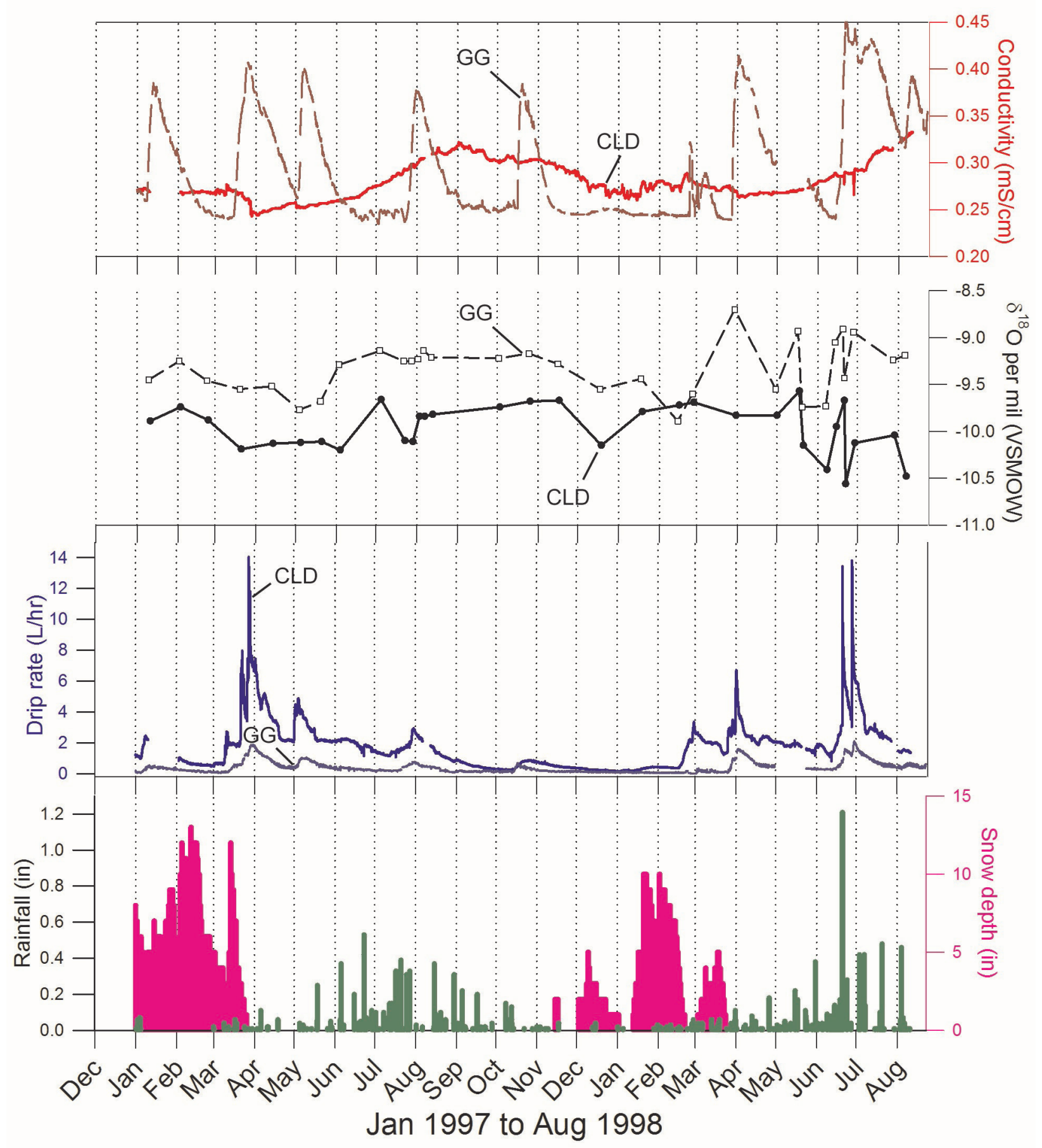

Figure 5. Time series records of drip rate and conductivity at two drip sites within Mystery Cave, Minnesota. The precipitation record is shown for reference. 
and large increase in drip rate causes little change in conductivity; only at peak drip rates above $\sim 10 \mathrm{~L} / \mathrm{hr}$ does the conductivity decrease, and during the recession may return to a higher value than that preceding the event (Figure 9).

\section{Drip Water Oxygen Isotope Data}

As seen in Figure 5, the drip waters show relatively little seasonal variation in $\delta^{18} \mathrm{O}$ composition measured with respect to VSMOW (Vienna Standard Mean Ocean Water) over the period studied; however, large individual recharge events can cause rapid changes in the isotopic composition of the drip water. For example, during the spring of 2001, large changes in

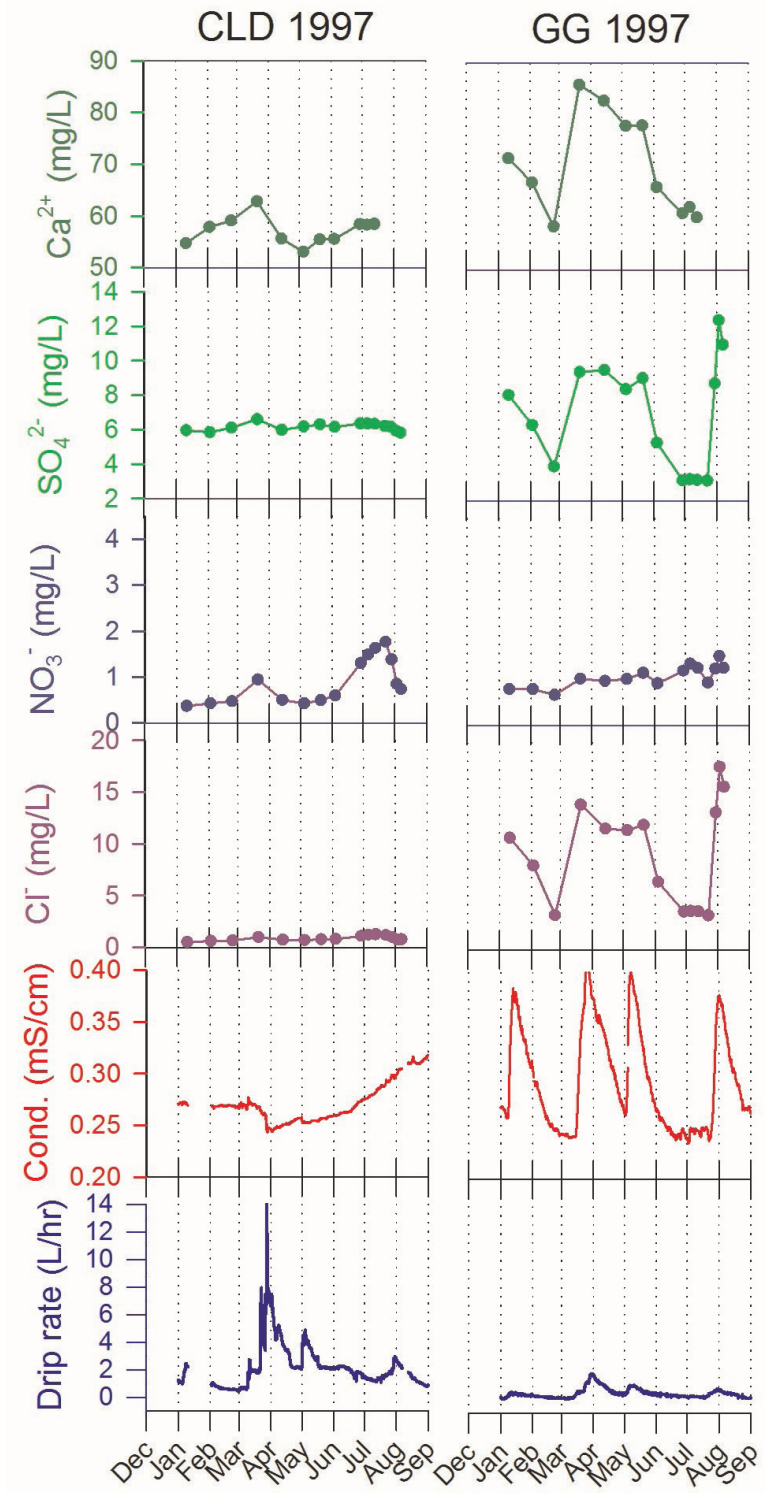

Figure 6. Chemical data obtained at both drip sites in the year 1997. drip rate at CLD caused changes in the $\delta^{18} \mathrm{O}$ of drip water of over $3.5 \%$ in the span of three months, in spite of minimal change in conductivity (Figure 10). From late March to mid-April, the $\delta^{18} \mathrm{O}$ of the CLD water decreased markedly with increased drip rate; however, during a rainstorm in early May, the $\delta^{18} \mathrm{O}$ of the water increased with increased drip rate. In contrast, the $\delta^{18} \mathrm{O}$ of the drip water at GG showed less variation during the same 3 -month time period, spanning a range of less than $0.5 \%$ (Figure 10 ).

It is interesting to note that the long-term mean $\delta^{18} \mathrm{O}$ isotopic composition values are significantly different between the two sites, with the CLD drips about $0.6 \%$ lower than the GG drips across the sampled time period.

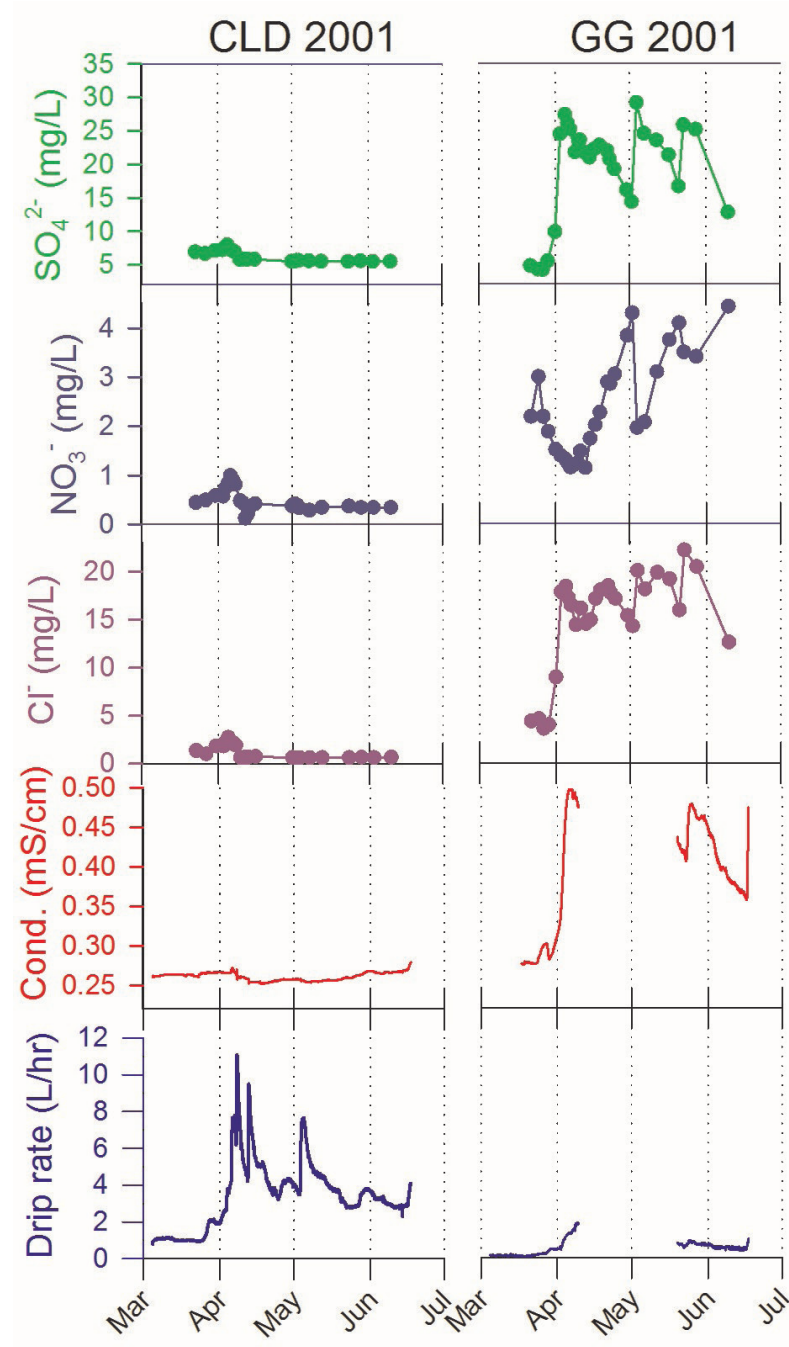

Figure 7. Chemical data obtained at both drip sites in the year 2001. Loss of data from the GG site between April and May resulted from equipment failure. 


\section{Discussion}

The drips at Garden of the Gods (GG) show two distinctly different types of water that discharge into the cave: one has a high $\mathrm{Cl}-\mathrm{SO}_{4}$ component in addition to the background $\mathrm{Ca}-\mathrm{Mg}-\mathrm{HCO}_{3}$ chemical signal. A significant increase in discharge at GG is invariably accompanied by the $\mathrm{Cl}-\mathrm{SO}_{4}$ chemical signal, however this is not the case at CLD. In fact, when large increases in discharge occur at CLD (from 2 to $14 \mathrm{~L} / \mathrm{hr}$ ), they are often accompanied by decreases in specific conductance, and do not show high chloride-sulfate chemistry.

The water that has an elevated $\mathrm{Cl}-\mathrm{SO}_{4}$ component most likely obtains this signature from the spring and fall seasonal application of fertilizers to the agricultural fields above the cave in the form of $\mathrm{KCl}$ and $\mathrm{CaSO}_{4}$, from the waste of livestock, or from some other anthropogenic source. It is possible that the cattle pond located just east of the cave entrance across the road may be a reservoir that contributes to this chemical signal (Figure 1). The elevation of the pond surface is approximately $1250 \mathrm{ft}$, while that of the bedding plane feeding the drips at GG is $\sim 1230 \mathrm{ft}$ (Figure 2). Whatever the source, the elevated $\mathrm{Cl}$ component is unlikely to be a natural chemical signal; natural waters collected within several other areas within Mystery Cave have also been analyzed for major ion chemistry, and show low chloride concentrations, generally less than $5 \mathrm{mg} / \mathrm{L}$ (Jameson and Alexander, 1994). $\mathrm{SO}_{4}$ could be derived by oxidation of pyrite in the bedrock (Palmer and Palmer, 1993), but would not be correlated with $\mathrm{Cl}$. This means that water with this chemical signal must have recharged after the onset of intensive agricultural activities above the cave, and is relatively modern water.

There is a strong correlation between the rate of flow at the drips at GG, and the chemistry of the drip waters. Only under recharge conditions is the elevated $\mathrm{Cl}-\mathrm{SO}_{4}$ component observed. Thus, the water that comes out of vadose storage under recharge conditions may not be very old, while that which contributes to the baseflow of the drips may be older.

The stable oxygen isotope data indicate that the vadose zone above the cave effectively dampens out the annual precipitation variability, which spans a range of approximately $15 \%$. Factors which may affect the isotopic composition of infiltrating recharge water include direct evaporation, exchange with the water vapor within voids in the vadose zone, and mixing with water already in storage. Transpiration will have a great
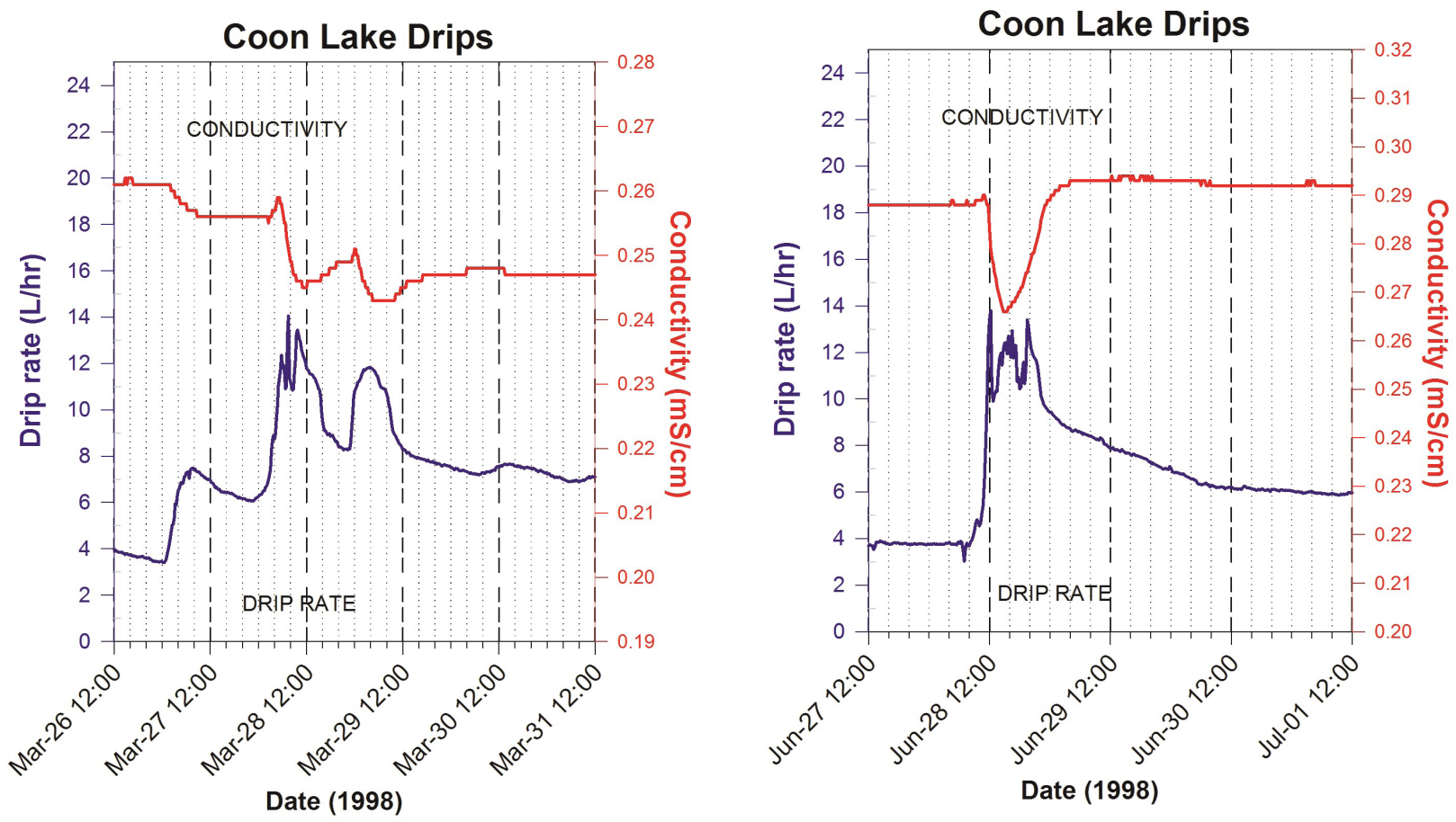

Figure 8. Detailed time series of conductivity response to drip rate at CLD. Top panel: 5-day record of snowmelt in March of 1997. Bottom panel: 4-day record of a summer rain storm event in 1998 (precipitation and long-term records shown in Figure 5). 
effect on the amount of water which actually infiltrates into the soil, but has been shown not to significantly fractionate the isotopic signature of the infiltrating water (Zimmerman et al., 1967).

The isotopic data seem to indicate that neither of the drips show much variation in their stable isotopic composition
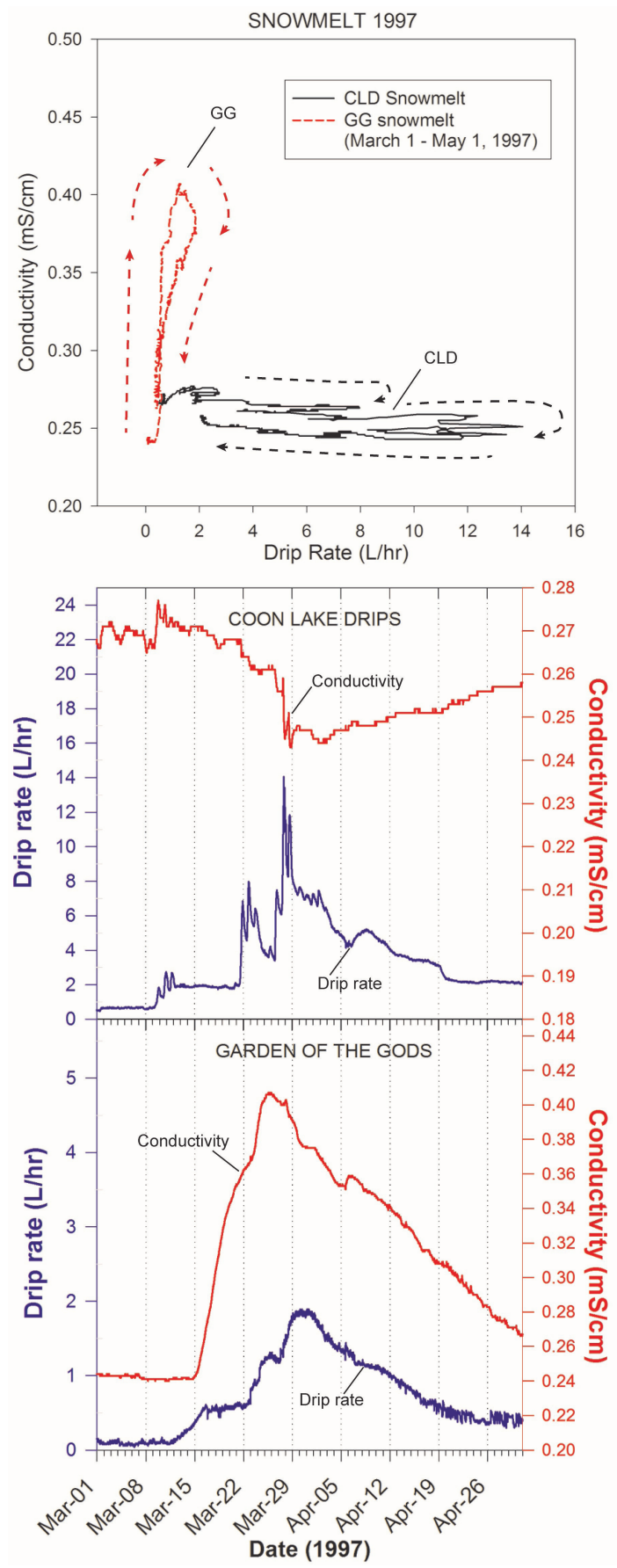

when sampled on a monthly basis during the study period; however, when sampled with greater frequency during a storm or snowmelt event, the data show that the isotopic composition of the drip waters are indeed subject to rapid change during large recharge events. During the spring snowmelt period of 1997, the monthly sampling was too infrequent to characterize changes
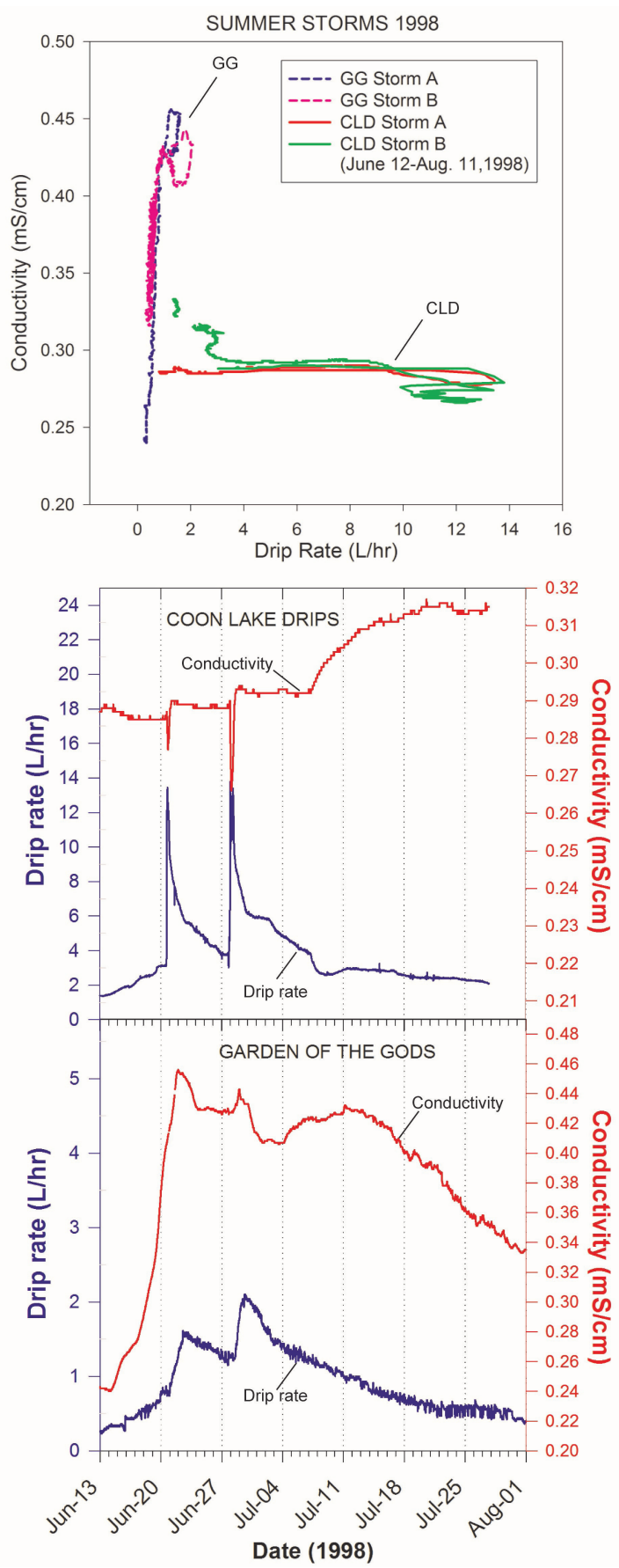

Figure 9. Hysteresis and time series records of discharge and conductivity during snowmelt and summer storm recharge events. 
in the isotopic composition that may have occurred at the drips; however, the snowmelt period of 2001 was sampled more frequently (weekly to sub-weekly) and provided a better record (Figure 10).

\section{Conclusions}

At least two reservoirs of water exist in the unsaturated zone above the cave. One has higher chloride and sulfate concentrations than the other. The higher chloridesulfate water is flushed out of the vadose zone under elevated flow conditions, and is stored as a reservoir within or above the bedrock. The higher chloridesulfate water is only observed at the slow-response, lower-flow drip site (GG) during recharge events, and is not similarly observed at fast-response, higher-flow drip site (CLD).

One hypothesis for the observed chemical and isotopic behavior is that the water at GG is dominated by pistonflow behavior in the vadose zone, while in contrast, CLD is dominated by better-integrated preferential flow paths leading from the surface to the cave, and thus exhibits more rapid changes in chemistry and discharge. In addition, the water feeding the drips at CLD is not likely to be sourced within the same recharge area as that feeding the drips at GG. The chemistry at
GG reflects a simple 2-component mixture, with the higher chloride-sulfate water expressed at the drips only at higher drip rates. Thus, a storage compartment for this water must exist above the cave. It is a possibility that this water comes from the nearby cattle pond, but this hypothesis has not been tested to date. Nevertheless, these chemical dynamics help shed light on the processes that serve to both rapidly transmit and store chemical constituents within the vadose zone in karst systems.

\section{References}

Alexander EC, Jr, Alexander SC, Grow SR, Wheeler BJ, Jameson RA, Guo L, Doctor DH, 1999.

Geochemical and isotopic evidence for multiple residence times in the same aquifer; Karst modeling; proceedings of the symposium. Karst Waters Institute Special Publication 5, 233-234.

Doctor DH, Alexander EC, 1998. Discharge, chemistry, and stable isotopic measurements of drip waters in Mystery Cave, Minnesota: records of hydrologic processes in the vadose zone. Proc. of Fluid Flow in Carbonates Mtg., Door Co. Wisc., Sept. 20-24, 1998.

Döerfliger N, Jeannin P-Y, Zwahlen F, 1999. Water vulnerability assessment in karst environments: a new method of defining protection areas using a multiattribute approach and GIS tools (EPIK method ). Environmental Geology 39 (2): 165-176.

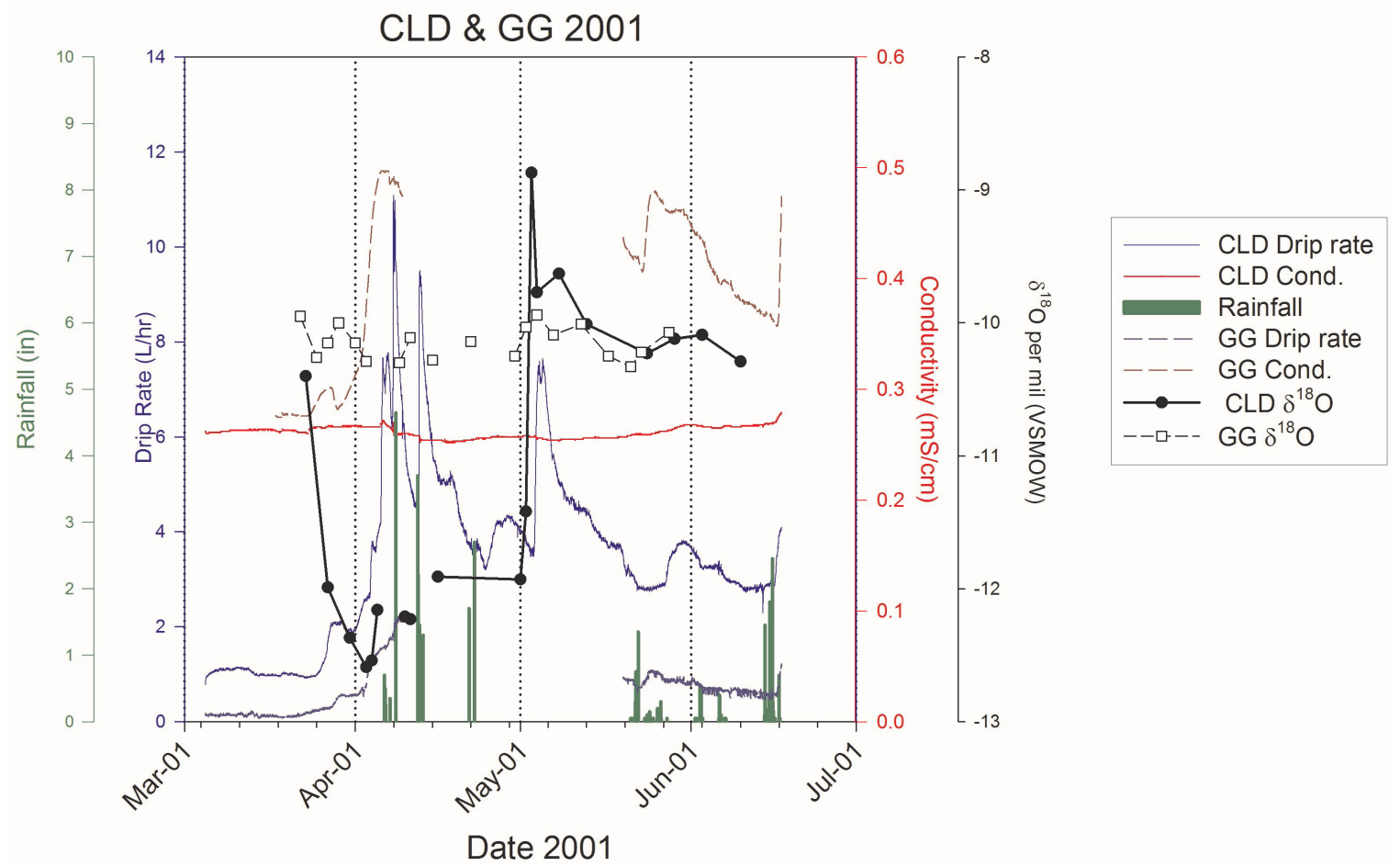

Figure 10. Oxygen isotope variability of drip waters compared to drip rate and conductivity during snowmelt of 2001. 
Fairchild IJ and Baker A. 2012. Speleothem Science: From Process to Past Environments. Chichester, West Sussex: Wiley-Blackwell, $450 \mathrm{p}$.

Fairchild IJ, Smith CL, Baker A, Fuller L, Spötl C, Mattey D, McDermott F, 2006. Modification and preservation of environmental signals in speleothems. Earth-Science Reviews 75 (1-4): 105-153.

Huebsch M, Fenton O, Horan B, Hennessy D, Richards KG, Jordan P, Goldscheider N, Butscher C, Blum $\mathrm{P}, 2014$. Mobilisation or dilution? Nitrate response of karst springs to high rainfall events: Hydrology and Earth System Sciences Discussions 11 (4): 4131-4161.

Jameson RA, Alexander EC, Jr, 1994. The Waters of Mystery Cave, Forestville State Park, Minnesota. Mystery Cave Resources Evaluation (Groundwater): Technical Report. Legislative Commission on Minnesota Resources (LCMR) Minnesota Dept. of Natural Resources, Minn. Pub. No.13-0624, 414 pp. http://www.leg.state.mn.us/ edocs/edocs.aspx?oclcnumber $=31884411$.

Kamas J, Bruthans J, Vysoka H, Kovařík M. 2015. Range of horizontal transport and residence time of nitrate in a mature karst vadose zone. International Journal of Speleology 44 (1): 49-59.

Palmer AN, Palmer MV. 1993. Geology and Origin of Mystery Cave, Forestville State Park, Minnesota. Mystery Cave Resources Evaluation:Technical Report. Legislative Commission on Minnesota Resources (LCMR) Minnesota Department of Natural Resources. 137 p., accompanied by "Extended profile of Mystery Cave", 20 sheets.

Wong CI, Banner JL, Musgrove M. 2011. Seasonal dripwater $\mathrm{Mg} / \mathrm{Ca}$ and $\mathrm{Sr} / \mathrm{Ca}$ variations driven by cave ventilation: Implications for and modeling of speleothem paleoclimate records. Geochimica et Cosmochimica Acta 75 (12): 3514-3529.

Zimmerman U, Ehhalt D, Munnich KO. 1967. Soilwater movement and evapotranspiration: changes in the isotopic composition of water. In Isotopes in Hydrology, IAEA: Vienna, pp. 567-584. 
